22. Breschi, S., Malerba, F. (1997). "Sectoral innovation systems: Technological regimes, Shumpeterian dynamics and spatial boundaries," in Systems of innovation: Technologies, institutions and organisations, C. Edquist, ed., Pinter, London, 130-156.

23. Cooke P., Uranga, MG, Extebarria G. (1997). "Regional innovation systems: Institutions and organisational dimensions". Research Policy, vol. 26, 475-491.

24. Sternberg, R. (2000). "Innovation networks and regional development. Evidence From the European Regional Innovation survey (ERIS): Theoretical concepts, methodological approach, empirical basis and introduction to the theme issue ". European Planning Studies, vol. 8, 4, 389-407.

Інститут географії Національної академії наук України, Київ

Стаття надійшла до редакції 12.05.2014

УДК 911.504

\title{
A.О. Шевцова
}

\section{КРЕАТИВНІ СТРАТЕГІЇ РОЗВИТКУ МІСТ: СУТНІСТЬ ПОНЯТТЯ ТА ПІДХОДИ ДО ЙОГО РОЗУМІННЯ}

\author{
А.А. Шевцова \\ КРЕАТИВНЫЕ СТРАТЕГИИ РАЗВИТИЯ ГОРОДОВ: СУТЬ ПОНЯТИЯ И ПОДХОДЫ К ЕГО ПОНИМАНИЮ \\ Институт географии Национальной академии наук Украины, Киев \\ Рассмотрено понятие «креативные стратегии» как стратегии развития городов с использованием инновационных \\ идей и творческого подхода к решению проблем, как правило, с акцентом на развитие культуры, исскуства, сохранение \\ исторического наследия и уникальности города. Изложены различные подходы к пониманию понятия «креативные \\ города». Даны примеры использования этой стратегии для различных проектов культурного развития в Европе. Одним \\ из наиболее оптимальных подходов к использованию креативных стратегий ныне является международный проект \\ «Сеть Креативных Городов ЮНЕСКО».
}

Ключевые слова: креативные стратегии развития городов; международное сотрудничество; креативные города; ЮHЕСКО.

\section{A. Shevtsova CREATIVE STRATEGIES OF URBAN DEVELOPMENT: THE CONCEPT ESSENCE AND APPROACHES TO ITS UNDERSTANDING Institute of Geography of the National Academy of Sciences of Ukraine, Kyiv}

The article reviews the concept of "creative strategies" as a strategy for urban development using innovative ideas and creative approach to problem solving, usually with emphasis on culture and arts development, preservation of historical heritage and uniqueness of the city. Various approaches to understanding the concept of "creative city" have been outlined. The examples of this strategy implementation in various projects of cultural development in Europe have been presented. One of the most effective approaches to creative strategies use is now an international project "Network of UNESCO Creative Cities".

Keywords: creative strategies of cities development; international cooperation; creative cities; UNESCO.

\section{Вступ}

В умовах активного процесу урбанізації та необхідності у зв'язку з цим пошуку способів поліпшення якості життя в міських поселеннях у різних державах світу креативні стратегії розвитку міст стали одним 3 популярних підходів до міського планування, який може стати вирішенням багатьох екологічних та соціальних проблем. Швидкі темпи глобалізації призвели до значних змін у структурі, функціонуванні та розвитку міст наприкінці XX століття.

Після різкого спаду виробництва і становлення сфери послуг, знань та інформації міста відчувають величезну конкуренцію в залученні інвестицій та труднощі у підтримці свого статусу. Нагальною проблемою багатьох міст також є питання поліпшення екологічного стану та створення сприятливих умов для життя мешканців.
Креативні стратегії розвитку міст були винайденні планувальниками та містобудівниками саме для вирішення цих проблем. Існує багато підходів да розуміння креативних стратегій у різних країнах, містах та міжнародних організаціях.

М е т о ю цієї статті є огляд підходів до розуміння креативних старатегій у плануванні та розвитку міст і виділення мережі креативних міст ЮНЕСКО як найбільш універсального та перспективного підходу.

\section{Підходи до розуміння креативних стратегій}

Креативні стратегії (від англ. creative - творчий) - це стратегії розвитку міста, що використовують певні інноваційні ідеї, творчий підхід до вирішення проблем, як правило з акцентом на розвиток 
культури, мистецтва, збереження історичної спадщини, підтримку визначних особливостей міста та розвиток його унікальності. Креативні стратегії використовуються неоднаково в різних містах та в різних культурних контекстах і не мають однозначного пояснення.

Вперше поняття «креативне місто» було розроблене Ч. Лондрі та Ф. Б’янчіні (Великобританія) в 1995 р. і описано першим у його книзі «Творче Місто. Інструментарій для міських новаторів», виданій у 2000 році. В його розумінні термін «креативне місто» є «поняттям, зосередженим на потенціалі індустрії культури, щоб зробити місто особливим та унікальним» [8, с. хxіi]. Ч. Лондрі стверджує, що ідея креативних міст полягає у вивільненні, приборканні та розвитку потенціалу людей та організацій через науку, мистецтво, технології або соціальну сферу для становлення індивідуальності міста.

Інноваційні ідеї Р. Флоріди (США) створили справжній бум в містоплануванні. У своїй праці «Підйом креативного класу» (2002) він популяризує поняття «креативний клас», наголошуючи, що творчі люди $є$ ключовим чинником економічного зростання міста [6]. Під терміном “креативний клас" Флоріда розуміє людей, які отримують дохід, займаючись творчістю: вчені, інженери, художники, музиканти та дизайнери. Щоб привабити креативний клас, місто повинно стимулювати 3 фактори «Т»: технології, талант та толерантність [6]. У розумінні вченого, креативні міста - це великі урбаністичні центри, такі як Сан-Франциско, Сіетл, Бостон, Денвер, Болдер та інші. Його підхід спрямований на те, щоб зробити місто швидкозростаючим та конкурентноспроможним на глобальному рівні, а також привабливим для відвідувачів. Слід зазначити, що теорію Флоріди активно критикують через пропагування досить спірної ідеї, що креативні міста можуть процвітати лише за наявності людей креативного класу. В такому підході відсутній акцент на унікальний розвиток міст, його важко застосувати для конкретної локальної економіки; крім того, фокус робиться на неоліберальну західну культуру (переважно США та Канаду), то ж він не підходить для деяких креативних міст інших регіонів світу.

На відміну від Р. Флоріди, Е. Пратт (Великобританія) наводить аргументи проти універсального підходу до креативних міст на користь унікального підходу до креативності з соціальним, культурним та економічним розуміння креативності, що є доповненням до конкретного соціально-історичного контексту [11, с.124].

Серед основних типів стратегій розвитку, характерних для креативних міст, Е. Пратт виділяє такі: увага до культурної та історичної спадщини; економічний розвиток, маркетинг місця та місцева конкуренція; соціальна інтеграція; фокус на ін- дустрію культури і творчості [11, с.15]. Такий підхід в основному базується на досвіді міст Великобританії та інших країн Свропейського Союзу.

Прикладом може бути проект «Креативні Micma», розроблений у 2008 р. за участю 15 європейських країн: Великобританії, Польщі, Чеської Республіки, Угорщини, Словаччини, Словенії, України, Швеції, Норвегії, Данії, Фінляндії, Естонії, Латвії, Литви та Росії. Цей прект $є$ переліком засобів, інструментів та онлайн майданчиків, що дозволяють розвивати ідеї та обмінюватися ними в рамках партнерства різних міст, організацій та навіть окремих осіб, що беруть активну участь у розробленні новаторських підходів до політики міста [2].

Інший проект, що використовує концепцію креативних міст, «Креативні Міста» для розвитку та просування творчого потенціалу в цетральноєвропейських містах, що впроваджується через Центральноєвропейську програму. Він спрямований на розвиток потенціалу креативної індустрії як локального та регіонального чинника розвитку 3 метою залучення інвестицій та створення робочих місць в П'яти центральноєвропейських містах: Лейпцигу (Німеччина), Генуї (Італія), Гданську (Польща), Любляні (Словенія) та Печі (Угорщина) [3].

Популярним є також проект «Европейська культурна столиця», започаткований Радою Міністрів Свросоюзу у 1985 р. з метою показати багатство і різноманіття європейських культур. Міста, які визначають та обирають для включення до проекту, представляють власну однорічну програму культурних заходів, щоб привернути міжнародну увагу та вдосконалити культурне життя й розвиток міста [5].

Окремо доцільно розглянути проект ЮНЕСКО.

\section{«Мережа Креативних Міст ЮНЕСКО»}

Одним із найпопулярніших проектів, що впроваджує креативні стратегії розвитку міст, є «Мережса Креативних Міст ННЕСКО». Наголос робиться на унікальності міста, стимулюванні розвитку соціальної креативності, збереженні культурноісторичної спадщини та відмові від конкуренції між містами на користь кооперації та взаємодопомоги через створення Мережі Креативних Міст [9]. Цей проект був розроблений у 2005 р. на базі загальної Декларації ЮНЕСКО про культурне різноманіття та ініціативи всесвітнього альянсу Культурного Різноманіття 2002 року. ЮНЕСКО визначає міста по всьому світу як центри, що мають передовий досвід у розвитку галузей декоративно-прикладного мистецтва, дизайну, гастрономії, кіномистецтва, літератури, медіа мистецтв та музики.

Слід зазначити, шо міста, включені до Мережі (табл. 1), є своєрідними «креативними центрами», 
Таблиця 1. Міста, що входять до «Мережі Креативних Міст ЮНЕСКО»

\begin{tabular}{|c|c|c|}
\hline $\begin{array}{c}\text { Назва міст - креативних центрів за різними } \\
\text { ознаками }\end{array}$ & $\begin{array}{c}\text { Чисельність населення, } \\
\text { тис. осіб * }\end{array}$ & $\begin{array}{c}\text { Рік визнання креативним } \\
\text { містом }\end{array}$ \\
\hline \multicolumn{3}{|l|}{ Міста - центри розвитку літератури } \\
\hline Едінбург (Шотландія, Великобританія) & 486 & 2004 \\
\hline Мельбурн ( Австралія) & 4,347 & 2008 \\
\hline Айова (США) & 67 & 2008 \\
\hline Дублін (Ірландія) & 1,024 & 2010 \\
\hline Рейк'явік (Ісландія) & 121 & 2011 \\
\hline Норвіч (Англія, Великобританія) & 140 & 2012 \\
\hline Краків (Польща) & 758 & 2013 \\
\hline \multicolumn{3}{|l|}{ Міста - центри розвитку кіномистецтв } \\
\hline Брадфорд (Англія, Великобританія) & 522 & 2009 \\
\hline Сідней (Австралія) & 4,391 & 2010 \\
\hline \multicolumn{3}{|l|}{ Міста - центри розвитку музики } \\
\hline Болонья (Італія) & 384 & 2006 \\
\hline Севілья (Іспанія) & 703 & 2006 \\
\hline Глазго (Шотландія, Великобританія) & 595 & 2008 \\
\hline Гент (Бельгія) & 248 & 2009 \\
\hline Богота (Колумбія) & 7,764 & 2012 \\
\hline Браззавіль (Конго) & 1,307 & 2013 \\
\hline \multicolumn{3}{|c|}{ Міста - центри розвитку прикладного та народного мистецтва } \\
\hline Асуан (Сгипет) & 209 & 2005 \\
\hline Санта-Фе (США) & 67 & 2005 \\
\hline Канадзава (Японія) & 462 & 2009 \\
\hline Ічхон (Південна Корея) & 2,900 & 2010 \\
\hline Ханчжоу (КНР) & 8,800 & 2012 \\
\hline Падучан (США) & 25 & 2013 \\
\hline Фабріано (Італія) & 32 & 2013 \\
\hline \multicolumn{3}{|l|}{ Міста - центри розвитку дизайну } \\
\hline Берлін (Німеччина) & 3,415 & 2005 \\
\hline Буенос-Айрес (Аргентина) & 2,890 & 2005 \\
\hline Санта-Фе (США) & 67 & 2005 \\
\hline Нагоя (Японія) & 2,266 & 2008 \\
\hline Кобе (Японія) & 1,545 & 2008 \\
\hline Шеньджень (Китай) & 10,547 & 2008 \\
\hline Сеул (Південна Корея) & 10,140 & 2010 \\
\hline Шанхай (Китай) & 24,150 & 2010 \\
\hline Сент-Етьєн (Франція) & 178 & 2010 \\
\hline Грац (Астрія) & 265 & 2011 \\
\hline Пекін (КНР) & 16,410 & 2012 \\
\hline \multicolumn{3}{|l|}{ Міста - центри розвитку медіа мистецтв } \\
\hline Ліон (Франція) & 1,551 & 2008 \\
\hline Анг'ян-ле-Бен (Франція) & 11 & 2013 \\
\hline Сапорро (Японія) & 1,918 & 2013 \\
\hline \multicolumn{3}{|l|}{ Міста-центри розвитку гастрономії } \\
\hline Попаян (Колумбія) & 265 & 2005 \\
\hline Ченду (Китай) & 14,047 & 2010 \\
\hline Естерсунд (Швеція) & 44 & 2010 \\
\hline Чонджу (Південна Корея) & 264 & 2012 \\
\hline Захле (Ліван) & 78 & 2013 \\
\hline
\end{tabular}

* - дані за Інтернет-джерелами 
що сприяють соціально-економічному зростанню за рахунок розвитку креативних індустрій, а також «соціально-культурними кластерами», які поєднують різні соціально-культурні громади для життєздатного міського середовища [1, с. 121]. До Мережі включено 41 місто, і їх кількість щорічно зростає (у 2012, наприклад, було 34).

Відповідно до головних пріорітетів ЮНЕСКО - «культурне різноманіття» та «сталий розвиток» основною метою створення «Мережі Креативних Міст ЮНЕСКО» є розвиток міжнародного співробітництва між містами і створення спільного партнерства [4].

Щоб стати членом «Мережі», місто має пройти спеціальну процедуру та подати заяву та звіт, що чітко описує наявні культурні активи та можливі напрямки співпраці 3 іншими містами мережі (наприклад, наявну інфраструктуру, освітні можливості, існуючі громадські ініціативи тощо). До заяви має бути включений офіційний лист від мера міста.

«Мережа Креативних Міст ЮНЕСКО» відіграє дуже важливу роль у реалізації креативних стратегій розвитку світу.

По-перше, одним із головних принципів Мережі $\epsilon$ визнання зростаючої важливості співпраці на місцевому рівні між державним і приватним секторами та громадянським суспільством, що дозволяє особам, які приймають рішення, працювати разом 3 громадами [1].

По-друге, головною метою «Мережі Креативних Міст ЮНЕСКО» є сприяння унікальному підходу до креативності. Використовуючи стратегії, що дали позитивні результати в певних містах, та поширюючи однакові ідеї, деякі міста можуть втратити власну ідентичність [11, с. 123]. ЮНЕСКО ж заохочує до різноманітності. Будучи міжнародною організацією, ЮНЕСКО виступає проти уніформізації (і багато в чому американізації) культури, а також за збереження культурного різноманіття світу [12].

По-третє, діяльність ЮНЕСКО спрямована на антиконцентрацію та децентралізацію культури, тому до Мережі входить багато невеликих міст, які не можна назвати «глобалізованими». У своїй більшості це невеликі та середні міста, такі як Едінбург, Болонья чи Санта-Фе. 3 метою посилення культурної децентралізації ЮНЕСКО дуже ретельно добирає міста до своєї мережі. Наприклад, Монреаль - місто франко-канадської, а не домінуючої англо-канадської культури, Санта-Фе - місто з багатою історією корінних індіанців та старовинними традиціями тощо.

«Мережа Креативних Міст ЮНЕСКО» також є організацією, заснованою на кооперації та взаємонавчанні. Кількість міст-учасників постійно зростає, проводяться щорічні конференції за участю учених, планувальників та мерів міст (наприклад, конференція у Монреалі у 2012 р. розглядала тему включення творчих підходів в управління бізнесом та виявлення інструментів стимулювання інноваційного потенціалу різноманітних організацій [4]). Одна з успішних форм діяльності - організація конкурсів. Наприклад, креативні міста дизайну у 2010 р. започаткували міжнародний конкурс постерів “CODE”, який отримав 807 відгуків від дизайнерів різних міст і закінчився міжнародною виставкою в кожному місті.

Слід зауважити, що вступ до «Мережі Креативних Міст ЮНЕСКО» не може автоматично перетворити місто на креативне. Цей проект не має переліку необхідних дій або стратегій, а лише подає основний принцип. Стратегії ж досягнення креативності можуть бути різними залежно від особливостей кожного міста.

Проект «Мережа Креативних Міст ЮНЕСКО» був започаткований у 2005 р., тому ще рано оцінювати грунтовні результати його впровадження. Проте вже можна стверджувати, що входження до Мережі - це можливість міжнародного співробітництва для міст, зацікавлених у застосуванні креативних стратегій.

\section{Висновок}

У сучасних умовах, коли Україна переживає чимало проблем, властивих багатьом світовим економікам (хаотичний розвиток міст, відсутність сучасних прогресивних стратегій їх розвитку, адаптації до швидких змін тенденцій світової економіки тощо), концепція креативних міст, що набуває поширення у світовому містоплануванні, має значний потенціал для вирішення багатьох урбаністичних проблем.

Аналіз різноманітних креативих стратегій показує, що концепція «Мережі Креативних Міст ЮНЕСКО» $\epsilon$ універсальним та водночас дуже локально-орієнтованим підходом до впровадження креативних стратегій у розвиток міста.

Ïї основні принципи:

- збереження унікальності міста;

- стимулювання творчого потенціалу мешканців;

- збереження культурно-історичної спадщини;

- забезпечення сприятливих умов для життя в місті.

Водночас, ця концепція наголошує на необхідності сталого збалансованого розвитку та відмові від конкуренції між містами на користь кооперації та взаємодопомоги у рамках співробітництва.

Багато українських міст мають значний потенціал та перспективу стати членами «Мережі Креативних Міст ЮНЕСКО». Завдяки спільним зусиллям адміністрації міста, громадських організацій, мешканців та бізнес-структур міста можуть стати на шлях сталого розвитку за рахунок збереження унікальності та визначних рис, розвитку культури 
та впровадження новітніх підходів до розвитку. Дослідження цих питань в українських реаліях
$€$ важливим i актуальним напрямом суспільної географіï.

\section{Лimepamypa}

1. Bandarin, Francesco. The Creative Power of Cities // City, Culture and society. - 2010. - № 4. - P.121 -122.

2. Creative Cities. British Council. N.p., n.d. Web. 28 Apr. 2012. [Електронний ресурс]. - Режим доступу: creativecities.britishcouncil. org/knowledge-and-ideas-bank/future_city_game

3. Creative cities. N.p., n.d. Web. 28 Apr. 2012. [Електронний ресурс]. - Режим доступу: http://www.creativecitiesproject.eu/en/index. shtml

4. Creative Cities Network Annual Meeting. UNESCO. N.p., n.d. Web. 28 Apr. 2012. [Електронний ресурс]. Режим доступу: http:// www.unesco.org/new/index.php?id=114135

5. European Capital of Culture. UNEECC. N.p., n.d. Web. 30 Apr. 2012. [Електронний ресурс]. - Режим доступу: http://www.uneecc. org/htmls/history1.html

6. Florida, Richard $L$. The rise of the creative class: and how it's transforming work, leisure, community and everyday life. - NY: Basic Books, 2002.

7. Kong, Lily, Justin Connor, and Patrick Mok. Asian Cities and Limits to Creative Capital Theory//Creative economies, creative cities: Asian-European perspectives. - Dordrecht, Netherlands: Springer, 2009. - P.135-150.

8. Landry, Charles. The creative city. A toolkit for urban innovators. Second Ed. New Stroud, UK: Comedia, 2008.

9. Lazzeretti, Luciana, and Masauyki Sasaki. Creative Industries and Creative policies in Japan. Creative industries and innovation in Europe: concepts, measures and comparative case studies. -London: Routledge, 2013. - P.136-152.

10. Pratt, Andy. Creative cities: Tensions within and between social, cultural and economic development: A critical reading of the UK experience//City, Culture and society. - 2010. - № 1.1, - P.13 - 20.

11. Pratt, Andy. The cultural contradictions of the creative city//City, Culture and society. - 2011. - № 2. - P.123 - 130.

12. Масаюкі Сасакі. Персональне інтерв’ю, Осака, 25 липня, 2012.

\section{References}

1. Bandarin, Francesco (2010). The Creative Power of Cities. City, Culture and society, 4, 121 -122.

2. Creative Cities. British Council. N.p., n.d. Web. 28 Apr. 2012: creativecities.britishcouncil.org / knowledge-and-ideas-bank / future_ city_game

3. Creative cities. N.p., n.d. Web. 28 Apr., 2012: http://www.creativecitiesproject.eu/en/index.shtml

4. Creative Cities Network Annual Meeting. UNESCO. N.p., n.d. Web. 28 Apr., 2012: http://www.unesco.org/new/index.php?id=114135

5. European Capital of Culture. UNEECC. N.p., n.d. Web. 30 Apr. 2012: http://www.uneecc.org/htmls/history1.html

6. Florida, Richard L. (2002). The rise of the creative class: and how it's transforming work, leisure, community and everyday life. NY: Basic Books.

7. Kong, Lily, Justin Connor, and Patrick Mok (2009). Asian Cities and Limits to Creative Capital Theory. Creative economies, creative cities: Asian-European perspectives. Dordrecht, Netherlands: Springer, 135-150.

8. Landry, Charles (2008). The creative city. A toolkit for urban innovators. Second Ed. New Stroud, UK: Comedia.

9. Lazzeretti, Luciana, and Masauyki Sasaki (2013). Creative Industries and Creative policies in Japan. Creative industries and innovation in Europe: concepts, measures and comparative case studies. London: Routledge, 136-152.

10. Pratt, Andy (2010). Creative cities: Tensions within and between social, cultural and economic development: A critical reading of the UK experience. City. Culture and society, 1.1, 13 - 20.

11. Pratt, Andy (2011). The cultural contradictions of the creative city. City, Culture and society, 2, 123 - 130.

12. Masayuki Sasaki (2012). Personal interview, Osaka, July 25, 2012. (From Ukr.). 